\title{
QAULLAN LAYYINA SEBAGAI MODEL KOMUNIKASI DI TENGAH MENJAMURNYA UJARAN KEBENCIAN
}

\author{
KhabibMusthofa ${ }^{1}$, Subiono Faqih $^{2}$ \\ Pascasarjana IAIN Palangka Raya ${ }^{1}$, \\ Kantor Urusan Agama Kec. Arut Selatan, Kab. Kotawaringin Barat ${ }^{2}$ \\ khabibmusthofa1996@gmail.com, subionopbun@gmail.com
}

\begin{abstract}
Hate speech is a lively reprehensible phenomenon on Indonesian social media, the impact of danger if it is not addressed wisely, through its circular related hate speech has been affirmed if hate speech is not handled properly and immediately, it can undermine the principle of the nation and nation with diversity. and protect the diversity of groups in this nation, especially in the era of people who have not fully matured in understanding democracy and difference. The attitude of carrying out hate speech also actually contradicts the ethics of communicating in Islam. One of the communication models taught is by a weak attitude or qaullan layyina. The Qur'an also teaches humans to communicate well, so that a harmonious relationship is created between the messenger and the recipient of the message, and the messages conveyed in the communication can be understood.
\end{abstract}

Keywords: hate speech, qaullan layyina

Kehadiran media sosial ibarat buah simalakama, ungkapan tersebut nampaknya tepat ditujukan ketika melihat kondisi saat ini. Media sosial sangat bermanfaat dan penuh dengan kemudahan semisal kemudah memperoleh informasi, sarana berkomunikasi, mendekatkan dengan yang jauh dsb. Sayangnya, masyarakat masih belum seluruhnya dewasa dalam memanfaatkan media sosial dengan bijak. Alhasil, konten negatif masih berseliweran dalam beragam bentuk (Hoaks, Pornografi, Ujaran Kebencian dll).

Sebagai buktinya, KOMINFO mempunyai catatan buram tentang masih banyaknya jumlah konten bermuatan negatif di berbagai media sosial yang telah ditangani. Lebih jelasnya perhatikan tabel dibawah ini;

Tabel 1.

Konten Bermuatan Negatif

\begin{tabular}{|l|l|l|}
\hline Twitter & Facebook dan Instagram & Youtube dan G+ \\
\hline 3.521 & 6.123 & 1.530 \\
\hline
\end{tabular}

Sumber: Laporan Tahunan KOMINFO 2019 
Selain hal tersebut temuan lain, "Berawal dari saling kecam tentang pilihan politik di sosial media, seorang warga Sampang, Madura, tewas ditembak temannya sendiri.". redaksi tidak mengenakkan tersebut diperoleh dari salah satu media kredibel (Voa.Indonesia) (Riski, 2018). Tentang ujaran kebencian, sebenarnya Kapolri telah mewanti-wanti dan menjelaskan dampak bahayanya apabila tidak disikapi dengan bijak, melalui surat edarannya terkait ujaran kebencian telah ditegaskan apabila ujaran kebencian tidak ditangani secara baik dan segera, maka dapat merongrong prinsip berbangsa dan bernegara Indonesia yang Berbhineka Tunggal Ika serta melindungi keragaman kelompok dalam bangsa ini, terlebih pada era masyarakat yang belum sepenuhnya matang memahami demokrasi dan perbedaan. (Rahman, 2015)

Tindakan yang dicontohkan warganet diatas sebenarnya jauh dari nilainilai Islam yang rahmatalilalamin juga Islam yang penuh kedamaian. Alquran pun sebenarnya telah menjelaskan, "Serulah (manusia) kepada jalan Tuhanmu dengan hikmah dan pelajaran yang baik dan bantahlah mereka dengan cara yang baik”. (QS. An-Nahl [16] ;125). Hal tersebut juga senada dengan pesan Prof. Dr Quraish Shihab, M.A, bahwa;

"yakni jangan layani kejahilannya, jangan jawab pelecehan dan makiannya, jangan menyiram bensin di percikan api, karena itu akan menyulut kobaran yang tak terkendali. Kalau ada yang memakimu, katakan padanya: "Jika makianmu benar, semoga Allah Mengampuniku dan jika salah, maka semoga Allah mengampunimu." Atau katakan kepadanya: "Jika engkau memakiku dengan sepuluh makian, engkau tidak akan medengar dariku walau satu makian" (Shihab, 2017a)

Dapat diambil pelajaran bersama dari ayat diatas dan Pesan Quraish Shihab bahwa ketika menyampaikan pesan/berkomunikasi harus dengan cara yang baik, bahkan ketika ingin membantah (coment/debat) sekalipun. Dari hal tersebut terlihat Islam mempunyai etika tersendiri dalam berkomunikasi. Model komunikasi seperti ini diajarkan oleh Musa dan Harun ketika menghadapi Firaun. Raja Firaun merupakan raja paling dzalim pada masanya, mengaku tuhan, bahkan kejahatannya di ceritakan dalam Alquran. Namun, Nabi Musa dan Harun diperintahkan untuk tetap lemah lembut dan bertutur kata yang baik meskipun kepada orang jahat dan dzalim sekalipun, ungkapan dalam kisah tersebut dikenal 
dengan qaullan layyina. Alquran mengajarkan manusia agar melakukan komunikasi dengan baik supaya, supaya tercipta hubungan yang harmonis antara penyampai pesan dengan penerima pesan, dan pesan-pesan yang disampaikan dalam komunikasi tersebut dapat dipahami. (Kadar, 2015)

Melihat fakta dan fenomena tidak mengenakkan diatas membuat penulis tertarik menyampaikan pesan penting sikap qaullan layyina melalui sebuah artikel ini. Dikatakan pesan penting karena seperti sabdanya "sesungguhnya Allah bersifat lemah lembut, dan menyenangi kelemah lembutan dalam segala persoalan” (HR. Bukhari dan Muslim Melalui Aisyah) (Shihab, 2014). Dengan judul "Qaullan Layyina Sebagai Model Komunikasi di Tengah Menjamurnya Ujaran Kebencian".

\section{METODE}

Tulisan ini termasuk kedalam penelitian pustaka. Pendekatan yang digunakan adalah pendektakan fenomenologis. Fenomenologis, merupakan pengalaman hidup yang sesungguhnya sebagai data dasar dari realita. Sehingga dalam kajian fenomenologis yang penting tidak memalsukan fenomena, melainkan dapat mendeskripsikannya seperti penampilannya. Selain itu penulis juga menggunakan metode retrospektif dalam menganalisis penelitian ini. Metode retrospektif yaitu melihat permasalahan yang ada kemudian mencari pemecahannya.

\section{PEMBAHASAN}

\section{Fakta Buram Ujaran Kebencian di Indonesia}

Adalah realita yang tidak bisa dipungkiri melihat kondisi di media sosial saat ini. Terkhusus terhadap konten negatif berbau ujaran kebencian beserta para netizen yang adabnya telah jauh melenceng dari nilai-nilai Islam. Kita melihat sendiri berbagai bentuk ujaran kebencian yang saban waktu diperlihatkan dengan gamblang baik postingan ataupun kolom komentar. Selain yang telah penulis sampaikan di Latar Belakang (Muqaddimah) masih banyak lagi temuan tidak mengenakkan tentang kondisi akhlak bermedia sosial dan akibatnya. 
Tidak hanya dunia politik dan keagamaan ujaran kebencian juga menyentuh berbagai lini kehidupan. Bahkan dari dunia hiburan dan olahraga. Terdapat redaksi berita yang tidak mengenakkan dari Tirto; id "Provokasi dan Ujaran Kebencian di Media Sosial membuat suporter Indonesia makin agresif Membunuh”. (Hanifan, 2018). Kasus Pembunuhan Haringga Sirla, Merupakan korban kebencian yang mengakar antara suporter. Haringga Sirila merupakan suporter militan pendukung Persija Jakarta yang hendak menonton tim kesayangannya berlaga melawan rivalnya Persib Bandung, alih-alih dapat melihat para pemain kebanggaannya berlaga, malah nasib naas menimpa dirinya yakni dikeroyok sekelompok suporter tak dikenal hingga meninggal dunia. Hal-hal tersebutlah yang menandakan bahwa ujaran kebencian merupakan kedzaliman yang besar.

Fakta lain penulis dapati, dari Laporan Tahunan Kementerian Komunikasi bahwa kasus tentang konten yang berbau negatif naik dalam 3 tahun terakhir, lebih jelasnya perhatikan tabel dibawah ini.

Tabel 2.

Jumlah Konten Negatif Tahun 2016, 2017, 2018.

\begin{tabular}{|c|r|}
\hline TAHUN & JUMLAH \\
\hline 2016 & 773.000 \\
\hline 2017 & 787.662 \\
\hline 2018 & 912.659 \\
\hline
\end{tabular}

Sumber: Laporan Tahunan KOMINFO 2019.

Salah satu fenomena yang masih teringat, rivalitas politik melahirkan labelling pada pendukungnya "Cebong dan Kampret", fenomena yang tidak sepatutnya menjadi viral di negeri ini. Beberapa fenomenanya dijelaskan dalam penelitian Abdulloh Hamid, Darwis, Santi Andriyani dengan judul Fenomena Politik Cebong dan Kampret di Indonesia Sebuah Analisis dari Perspektif Pemikiran Politik dalam Islam. Kondisi ini menjadikan masyarakat terpolarisasi secara politik. Peristiwa persekusi dan penolakan antar kedua kubu cukup sering terdengar dalam pemberitaan media nasional dan menjadi perdebatan publik di ruang maya. Seorang ibu yang mengenakan kaus “\#DiaSibukKerja”mendapat 
intimidasi dari massa kaus “\#2019GantiPresiden” di Car Freed Day, Bundaran HI, Minggu pagi (Hamid et al., 2018). Peristiwa-peristiwa yang mengandung keresahan, perpecahan, dan postingan tidak beradab bukan tidak mungkin akan berpotensi muncul kembali seiring dengan bergulirnya pilkada serentak 2020 .

Tidak hanya itu, beberapa dampak bahayanya ujaran kebencian selain menimbulkan aksi kejahatan, Savic dalam bukunya Seri Cerdas Hukum; Cerdas Menghadapi Pencemaran Nama Baik, Ujaran Kebencian dan Hoaks juga mengatakan bahwa ujaran kebencian sangat begitu berbahaya, pada yang titik paling parah bisa menimbulkan genosida. Sedangakan pada titik yang paling rendah bisa menimbulkan konflik horizontal (Mauludi, 2018). Istilah Genosida begitu mengerikan dijelaskan dalam Hukum Pidana International bahwa Genosida merupakan kejahatan yang dilakukan dengan sengaja untuk menghancurkan seluruh atau sebagian kelompok atas dasar kewarganegaraan, etnis, ras dan agama. Tindakan itu meliputi pembunuhan terhadap anggotaanggota kelompokmengakibatkan kerusakan serius terhadap fisik dan mental anggota kelompok.

Untuk itu, demi terciptanya suasana kehidupan yang harmonis antar anggota masyarakat, maka harus dikembangkan bentuk-bentuk komunikasi yang beradab. Jalaludin Rahmat menggambarkan yaitu sebuah bentuk komunikasi di mana sang komunikator akan menghargai apa yang mereka hargai; ia berempati dan berusaha memahami realitas dari perspektif mereka. Pengetahuannya tentang khalayak bukanlah untuk menipu, tetapi untuk memahami mereka, dan bernegosiasi dengan mereka, serta bersama-sama saling memuliakan kemanusiaannya. Adapun gambaran kebalikannya yaitu apa-bila sang komunikator menjadikan pihak lain sebagai obyek; ia hanya menuntut agar orang lain bias memahami pendapatnya; sementara itu, ia sendiri tidak bisa menghormati pendapat orang lain. Dalam komunikasi bentuk kedua ini, bukan saja ia telah mendehumanisasikan mereka, tetapi juga dirinya sendiri. (Bahrudin, 2010). 


\section{Menggali Makna Qaullan Layyina.}

Setiap memulai berkomunikasi, Islam mempunyai sapaan singkat tapi penuh cinta "Assalamualikum warahmatullahiwabarakatuh". Islam hadir dengan penuh pesan damai. Kalimatnya memang singkat tapi sarat aka makna, dengan saapaan tersebut, orang muslim selalu berharap dan memohon keselamatan bagisaudara-saudaranya. (Musyadi, 2005)

Al-Qur'an mengajarkan manusia agar melakukan komunikasi dengan baik, supaya tercipta hubungan yang harmonis antara penyampai pesan dengan penerima pesan, dan pesan-pesan yang disampaikan dalam komunikasi tersebut juga dapat dipahami. Untuk itu, Al-Qur'an mengajarkan etika dalam berkomunikasi, dan model komunikasi terhadap manusia sesuai dengan situasi dan kondisi lawan bicara, hal tersebut juga termasuk etika dalam berkomunikasi ketika bermedia sosial.

Salah satu etikanya ketika berkomunikasi, Islam mengajarkan harus dengan baik dan penuh sopan satun. Allah SWT Berfirman:

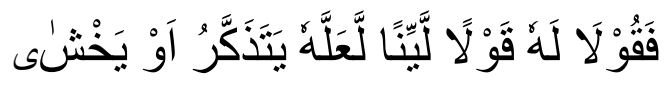

44. maka berbicaralah kamu berdua kepadanya (Fir'aun) dengan kata-kata yang lemah lembut, mudah-mudahan dia sadar atau takut. (QS. Thaha: 44)

Syaikh Ali As-Shabuni dalam Kitab Shawatut Tafasir miliknya menafsirkan redaksi ayat tersebut "pergilah kamu berdua kepada Firaun, sesungguhnya adia telah melampui batas, maksudnya adalah dia kejam, dan kelewatan durhaka serta sesat. "maka berbicaralah kamu berdua kepadanya dengan kata-kata yang lemah lembut”. Berkatalah kalian berdua kepada Firaun dengan lemah lembut dan halus "mudah-mudahan ia ingat dan takut," semoga dia ingat akan keagungan Allah atau takut akan siksanya, sehingga dia menghentikan kesatannya. (Ash-Shabuni, 2013)

Term qaullan layyina dijelaskan dalam Alquran melalui Surat Thaha ayat 44 tersebut dijelaskan Imam Ibnu Katsir dalam kitab tafsirnya bahwa pada garis besarnya pendapat mereka menyimpulkan bahwa Musa dan Harun diperintahkan oleh Allah Swt. agar dalam dakwahnya kepada Fir'aun memakai kata-kata yang lemah lembut, sopan santun, dan belas kasihan; Dimaksudkan agar kesannya lebih 
mendalam dan lebih menggugah perasaan serta dapat membawa hasil yang positif. Konsep qawlan layyina dalam ayat ini merupakan model komunikasi Nabi Musa dan Harun kepada Fir'aun (musuhnya).

Searah dengan hal diatas, Prof. Dr Quraish Shihab dalam tafsirnya Almisbah menjelaskan $\mathrm{Fa}$ qula lahu qaulan layyinan/ maka berbicaralah kamu berdua kepadanya dengan kata-kata yang lemah lembut, menjadi dasar tentang perlunya sikap bijaksana dalam berdakwah yang antara lain ditandai dengan ucapan-ucapan sopan yang tidak menyakitkan hati sasaran dakwah. Karena Fir'aun saja, yang demikian durhaka, masih juga harus dihadapi dengan lemah lembut. Memang dakwah pada dasarnya adalah ajakan lemah lembut. Ini tentu saja bukan berarti bahwa juru dakwah tidak melakukan kritik, hanya saja itu pun harus disampaikan dengan tepat bukan saja pada kandungannya tetapi juga waktu dan tempatnya serta susunan kata-katanya, yakni tidak dengan memaki atau memojokkan(Shihab, 2017b). Kadar. M Yusuf, melanjutkan dalam pesan-pesan Al-Qur'an menuntun kita agar mempergunakan bahasa yang lemah lembut, jelas, tegas dan menyentuh jiwa. (Kadar, 2015)

Pesan Alquran tentang model komunikasi seperti ini sudah saatnya dimiliki masyarakat dunia maya ditengah menjamurnya ujaran kebencian. Bukan saatnya lagi dalam berkomunikasi ada muatan ujaran kebencian didalamnya. Bukan pula menyikapi ujaran kebencian dengan membalas melalui ujaran kebencian pula. Karena sikap tersebut seperti halnya menyiram bensin dalam percikan api. Nabi Musa dan Harun mencontohkan dalam menyikapi Raja Firaun yang merupakan raja paling dzalim pada masanya, mengaku tuhan, bahkan kejahatannya di ceritakan dalam Alquran. Namun, Nabi Musa dan Harun diperintahkan untuk tetap lemah lembut, bertutur kata yang sopan.

Teladan tersebut penting untuk diaktualisasikan. Pertama, Tidak pantas jika kita berkomunikasi dengan lawan bicara/warganet/netizen yang kejahatannya tidak sedzalim Raja Firaun dalam berkomunkasi ada muatan ujaran kebencian didalamnya. Kedua, Nabi Musa dan Harun manusia paling shaleh pada masanya, dalam berkomunikasi dengan orang paling dzalim masih dengan penuh kelembutan dan sopan santun. Sudah sepatutnya kita yang tidak seshaleh dan 
setaqwa Musa dan Harun, bahkan belum dijamin masuk surga memiliki mental berkomunikasi seperti kedua nabi tersebut dan diaktualisasikan dengan sungguhsungguh dalam kehidupan sehari-hari.

\section{Qaullan Layyina Sebagai Model Komunikasi di Tengah Menjamurnya Ujaran Kebencian}

Pada 30 Juli 2018 lalu, masih terniang diingatan kejadian yang menyayat hati bangsa Indonesia. terjadi pembakaran dua vihara dan lima kelenteng di Tanjung Balai, Sumatera Utara. Seperti yang diberitakan. Kerusuhan ini berawal dari keluhan seorang ibu soal speaker mesjid di dekat rumahnya yang disetel dengan volume tinggi. Sebagian warga tak terima dengan keluhan itu sehingga perdebatan berujung ke kantor polisi. Di situ sudah ada kerumunan masa. Dalam waktu hitungan jam, massa bertambah dan bergerak ke Vihara Juanda. Gerakan massa bertambah sehingga akhirnya ada dua vihara dan lima kelenteng terbakar.

Dijelaskan dalam (Tirto.id, 2017) Beberapa hari sejak kejadian itu, ada yang dijadikan tersangka tersebab ditengarai menyebarkan ujaran kebencian lewat akun Facebook-nya. Seorang berinisial AT, warga Jakarta, ditangkap setelah ia mengirim status yang menggiring kejadian Tanjung Balai dan diarahkan agar seperti kerusuhan 1998.AT menulis dalam akun media sosial miliknya, "Tanjung Balai Medan Rusuh 30 Juli 2016...!! 6 Vihara dibakar buat Saudara Muslimku semua mari rapatkan barisan... Kita buat Tragedi 98 terulang kembali." Sikap Netizen AT tersebut jika dicermati sesuai dengan maksud perkataan Quraish Shihab bahwa menyiram bensin dalam percikan api. Bukannya meredam dan memperbaiki suasana malah menghidupkan kobaran api tanpa henti. Sikap seperti tersebut yang sebenarnya harus dibuang jauh-jauh.

Menyikapi hal tersebut Tim Siber Kreasi dalam bukunya; Demokrasi damai Era Digital dengan lugas menjelaskan ditengah pesan kebencian yang meningkat di ranah online salah satu aspek yang paling perlu dihindari adalah narasi “perang”.(Siberkreasi, 2019) Dengan tidak mengunakannya narasi perang tersebut yang merupakan manifestasi dari nilai-nilai qaullan layyina. 
Allah SWT Berfirman dalam Al-Isra Ayat 53,



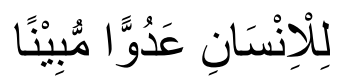

53. Dan katakanlah kepada hamba-hamba-Ku, "Hendaklah mereka mengucapkan perkataan yang lebih baik (benar). Sungguh, setan itu (selalu) menimbulkan perselisihan di antara mereka. Sungguh, setan adalah musuh yang nyata bagi manusia.

Menurut Ibnu Katsir, dalam ayat tersebut Allah subhannahūwa ta'ālā memerintahkan kepada hamba-hamba-Nya yang beriman agar berkata dengan perkataan yang baik (ahsan) atau menggunakan kata-kata terbaik ketika berkomunikasi atau ketika menyampaikan, menganjurkan, mengajak ajaran Islam kepada sesama. Jika mereka tidak berbuat demikian maka di antara mereka akan terkena hasutan setan yang akan berdampak pada perilaku mereka, sehingga akan terjadi pertengkaran dan permusuhan.

Memiliki mental qaullan layyina adalah alternatif dari upaya mewujudkan pesan tersebut, terlebih lagi hidup di Indonesia yang penuh dengan keberagaman. Sebagai netizen sudah seyogyanya untuk berbuat kepada kebaikan begitupun ketika bermedia sosial. Semua orang mendambakan suasana hidup yang aman dan tenteram tenang dan damainya suatu masyarakat dan bangsa. Hasyi Musyadi melanjutkan bahwa kondisi tersebut hanya akan terjadi jika masyarakat didalamnya memiliki integritas didalam jiwanya telah menyatutata krama dan sopan santun.(Musyadi, 2005)

Bukti ilmiah pentingnya bersikap Qaullan Layyina dijelaskan dalam penelitian Praptomo Baryadi dengan hasil kesimpulan bahwa;

"Perilaku berbahasa yang tidak sopan dapat menghambat pendidikan karakter anak didik. Perilaku berbahasa yang tidak sopan dapat mengakibatkan ketidakstabilan psikologis pada anak didik. Ketidakstabilan psikologis ini pada gilirannya akan menjadi hambatan dalam internalisasi nilai-nilai dalam diri anak didik. Perilaku berbahasa yang tidak sopan yang dilakukan oleh pendidik dapat menyebabkan krisis keteladanan bagi anak didik".(Baryadi, 2008)

Tidak sopannya dalam berkomunikasi selain tidak selaras dengan nilainilai ajaran agama ternyata juga berdampak kepada komunikan atau lawan bicara. 
Dapat diambil contoh perilaku berkomunikasi yang tidak sopan menyebabkan ketidakstabilan psikologis. Beberapa contohnya adalah seperti takut, kecewa, minder, patah hati, frustasi, tertekan (stress), sakit hati, malu, benci, dendam, ekstrem, agresif, marah, depresi. Dari hal tersebut dapat kita ambil pelajaran bersama bahwa bersikap tidak santun dalam berkomunikasi selain memancing konflik juga mempunyai dampak kepada komukan/lawan bicara/warganet. dampaknya tersebutlah yang tidak baik untuk diwariskan kepada generasi mendatang.

Berdasarkan Pesan dan nilai qaullan layyina diatas kita dapat ambil pelajaran bersama bahwa dalam menghadapi maraknya ujaran kebencian sudah sepatutnya bukan dibalas dengan ujaran kebencian pula, karena sikap tersebut bukannya memadamkan percikan api, tapi malah menyirami percikan api tersebut dengan bensin sehingga makin bergelora kian besar. Kedua, urgensi sikap qaullan layyina selain sebagai peredam perpecahan dan memperkuat harmonisasi dalam berkehidupan, ternyata mempunyai nilai penting lainnya yakni dapat menumbuhkan nilai-nilai pendidikan karakter pada generasi kita. Sesuai dengan penelitian Praptomo Baryadi seseorang yang tidak memiliki sikap sopan dan santun dalam berkomunikasi mempunyai dampak kepada lawan bicara seperti takut, kecewa, minder, patah hati, frustasi, tertekan (stress), sakit hati, malu, benci, dendam, agresif, marah, depresi, gila, dll.

Nilai-nilai dan pesan diatas penting, terlebih dalam menyambut pilkada serentak 2020. Jangan sampai fenomena buram pesta demokrasi pada tahun sebelumnya terulang kembali. Baru-baru ini Presiden Republik Indonesia berpesan "Jangan adalagi politik sara-, jangan ada lagi ujaran kebencian, jangan lagi saling fitnah, jangan lagi ada saling hujat". Pesan yang dilansir oleh detikNews. (Erwanti, 2020)

\section{Upaya Membangun Ruang Publik yang Damai}

Jika berkaca kepada potret demokrasi Indonesia, kita masih diingatan ketika eksistensi cebong vs kampret di media sosial menjadi tontonan saban waktu dikala pemilu presiden Republik Indonesia 2019. Ucapan olok-olok tidak 
manusiawai kemudian saling serang ujaran kebencian antar kedua belah “cebongers dan kampretos” sudah menjadi makanan warganet. Sikap kedua belah phak tersebut sama sekali tdak mencerminkan masyarakat indonesia yang adil dan beradab, lebih parahnya lagi saling sikut antar keduanya tidak hanya di media sosial namun dibawa di kehidupan sesungguhnya.

Padahal Allah SWT Befirman:

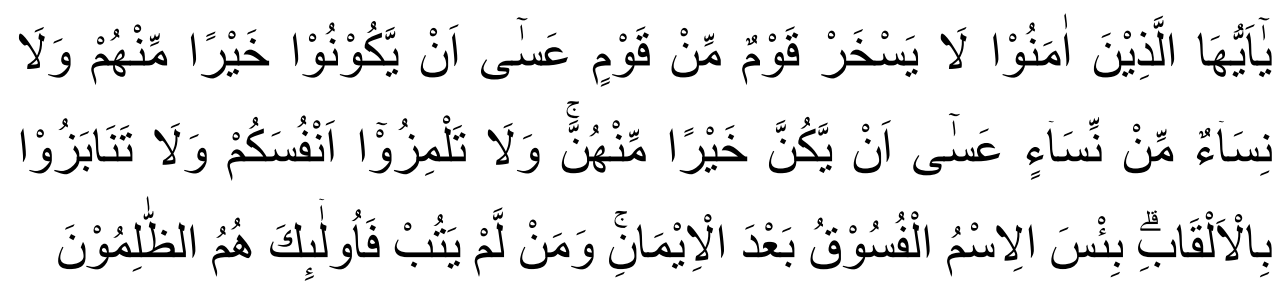

11. Wahai orang-orang yang beriman! Janganlah suatu kaum mengolokolok kaum yang lain (karena) boleh jadi mereka (yang diperolok-olokkan) lebih baik dari mereka (yang mengolok-olok) dan jangan pula perempuanperempuan (mengolok-olokkan) perempuan lain (karena) boleh jadi perempuan (yang diperolok-olokkan) lebih baik dari perempuan (yang mengolok-olok). Janganlah kamu saling mencela satu sama lain dan janganlah saling memanggil dengan gelar-gelar yang buruk. Seburukburuk panggilan adalah (panggilan) yang buruk (fasik) setelah beriman. Dan barangsiapa tidak bertobat, maka mereka itulah orang-orang yang zalim. (Qs. Alhujurat; 11)

KH. Hasyim Muzadi dalam bukunya Radikalisme Hancurkan Islam menjelaskan ayat diatas memiliki tiga pesan. Pertama, kita dilarang untuk mencaci atau mencemooh keadaan suatu kaum. Sebab mereka yang dicaci dan dicemooh kanitu bleh jadi lebih baik dari kita. Kedua, para wanita tidak boleh mencaci dan mencemoohkan wanita lain. Kenapa ayat ini ditjukan sesifik kepada kaum wanita? Karena memang benar wanita sesuai kenyataan wanita lebih potensial untuk saling menjelekkan. Ketiga, larangan untuk memanggil seseorang dengan panggilan yang tidak disukainya dengan maksud mengejek sehingga membuat orang marah dengan. Sikap-sikap tersebut yang akan menimbulkan permusuhan diantara mereka.(Musyadi, 2005). Qs. Alhujurat dan penjelasandari K.H Hasyim Muzadi tersebut merupakan cerminan dari maksud ujaran kebencian. Jika suatu ketika kita menemukan saudara-saudara kita kurang akrab, kurang 
harmonis dan cenderung saling memsuhi dan menjelekkan maka kita harus benarbenar berupaya mendamaikan keduanya.(Musyadi, 2005)

Sejumlah hoaks dan ujaran kebencian pada masa Pemilihan Umum 2019 dinilai akan kembali muncul pada pemilihan kepala daerah serentak 2020. Oleh karena itu, kabar bohong dan ujaran kebencian ini perlu disikapi dengan serius agar tidak terjadi konflik horizontal masyarakat.(Musktika, 2019) agar potensi keresahan, konflik dan perpecahan 2019 tidak terulang sudah sepatutnya kita memulai dari diri sendiri mencoba sebagai motor penggerak media sosial yang damai.

Dalam proses pemberantasan ujaran kebencian, tidak sepatutnya selalu mengkambinghitamkan pemerintah karena belum maksimalnya dalam menghilangkan penyakit tersebut. Alangkah baiknya harus benar-benar dimulai dari diri sendiri. Pesan Quraish Shihab terkait hal tersebut bahwa kesejahteraan sosial dimulai dari perjuangan mewujudkan dan menumbuhsuburkan aspek-aspek akidah dan etika pada diri pribadi yang seimbang akan lahir masyarakat seimbang. Masyarakat islam pertama lahir dari Muhammad SAW. Melalui kepribadian beliau yang sangat mengagumkan. Pribadi ini melahirkan keluarga seimbang Khadijah, Ali Bin Abi Thalib, Fatimah Az-Zahra dan lain-lain kemudian lahir diluar keluarga itu Abu Bakar Ash-Shidiq dan sebagainya yang juga membentuk keluarga dan demikian seterusnya, sehingga pada akhirnya terbentuklah masyarakat yang seimbang antara keadilan dan kesejateraan sosial. (Shihab, 2007)

Melalui model komunikasi seperti qaullan layyina mampu sebagai alternatif melawan ujaran kebencian dan ikhtiyar kita dalam membangun media sosial yang lebih beradab. Setelah mengenali ujaran kebencian, dalam modul loka karya penyuluh agama menjelaskan bahwa langkah berikutnya adalah melawan ujaran kebencian tersebut dengan membuat narasi tandingan atau kontranarasi, dengan kata lain menciptakan narasi baru/alternatif. Kontranarasi adalah balasan tangkisan singkat, cepat, dan langsung untuk melawan ujaran kebencian. Kontranarasi digunakan sebagai instrumen untuk melawan ekspresi kebencian yang sangat nyata. Dengan demikian, ruang publik tidak dikuasai oleh ujaran 
kebencian saja, namun juga narasi damai yang melemahkan narasi kebencian. (Agama, 2018)

Begitu penting memperjuangkan kehendak tanpa kekerasan, tetapi dengan penampilan simpatik, bahkan meskipun ketika tukar pikiran sedang memanas hati harus tetap dingin dan bersahabat (Shihab, 2014). Alquran pun telah mewantiwanti dalam (QS Fushilat [41]: 34) "tidak sama kebaikan dan kejahatan. Tolaklah kejahatan itudengan cara yang terbaik, maka cara yang demikian akan menjadikan orang antara kamu dan dia ada permusuhan, tiba-tiba menjadi teman yang sangat setia.

Ayat diatas selaras dengan maksud kontranarasi dengan pendekatan qaullan layyina, dan konsep inilah yang perlu ditanamkan kepada setiap individu, karena apabila semua pihak memahami hal tersebut bukan tidak mungkin tidak akan diketemukannya makian di media sosial. Selanjutnya, tidak hanya individu, kontranarasi dengan pendekatan qaullan layyina juga perlu dukungan dan dimiliki setiap figur yang berpengaruh seperti praktisi pemerintahan, publik figur, akademisi dan mereka yang memilik pengikut banyak yang memungkinkan mendapat audiens yang banyak dalam waktu singkat. (Agama, 2018)

Pusat Studi Agama dan Demokrasi (PUSAD dan Masyarakat Anti Fitnah Indonesia) dalam buku Panduan Melawan Hasutan Kebencian menegaskan langkah tersebut bukan tidak mungkin akan membuat ruang publik akan terebut. yaitu ruang publik yang awalnya sudah dipenuhi dengan ekspresi kebencian, menggantikannya dengan ekspresi cinta dan fakta. (Agama, 2018)

Selanjutnya, melalui perjuangan individu dan kerjasama antar pihak tersebutlah besar harapan mampu merubah dan mempengaruhi diskusi dimasyarakat sehingga mengubah narasi yang bergulir di publik. Narasi dan diskusi yang saban waktu di perlihatkan di media sosial amat berperan penting. Karena dapat mempengaruhi warganet dalam berfikir, memahami kondisi sekitar bahkan mengambil keputusan. Jika narasi ujaran kebencian lebih banyak beredar dimasyarakat Bahkan, apabila masyarakat meyakininya sebagai hal yang benar bukan tidak mungkin akan memantik konflik dan perpecahan bangsa pun terjadi 
(Agama, 2018). Begitu juga sebaliknya apabila media sosial lebih banyak diisi dengan narasi damai, lemah lembut, sopan santun seperti halnya model komunikasi qaullan layyina maka buah dari itu semua adalah hadirnya media sosial yang berkualitas dan beradab.

\section{KESIMPULAN}

Ujaran kebencian merupakan tindakan tercela, dan dampaknya sangat berbahaya juga bertolak belakang dengan ajaran etika berkomuikasi dalam Islam. Salatah satu etika berkomunikasi dalam Islam adalah qaullan layyina, atau dengan lemah lembut, sopan dan penuh dengan kebaikan. Pesan dan nilai qaullan layyina dalam menghadapi maraknya ujaran kebencian sudah sepatutnya perlu ditanamkan setiap individu maupun kelompok masyarakat. konsep ini juga mengajarkan ujaran kebencian bukan direspon dengan ujaran kebencian pula, karena sikap tersebut bukannya memadamkan percikan api, tapi ibarat menyiram percikan api tersebut dengan bensin yang membuat api kian menggelora. 


\section{DAFTAR PUSTAKA}

Ash-Shabuni, S. M. A. (2013). Shafwatut Tafasir; Tafsir-Tafsir Pillihan. Amzah.

Bahrudin. (2010). Prinsip-Prinsip Komunikasi dalam Alquran. Jurnal Ilmu Dakwah, 4(No. 15).

Baryadi, P. (2008). Perilaku berbahasa yang tidak sopan dan dampaknya bagi pendidikan karakter. Prosiding Seminar Nasional "Ketidaksantunan Berbahasa Dan Dampaknya Dalam Pembentukan Karakter."

Erwanti, M. O. (2020). Jokowi: Jangan Ada Lagi Politik SARA dan Ujaran Kebencian di Pilkada 2020. DetikNews. https://news.detik.com/berita/d4872590/jokowi-jangan-ada-lagi-politik-sara-dan-ujaran-kebencian-dipilkada-2020

Hamid, A., Darwis, D., \& Andriyani, S. (2018). Fenomena Politik Cebong dan Kampret di Indonesia: Sebuah Analisis dari Perspektif Pemikiran Politik dalam Islam. POLITEA. https://doi.org/10.21043/politea.v1i1.4320

Kadar, M. Y. (2015). Tafsir Tarbawi; Pesan-Pesan Alquran Tentang Pendidikan (Jakarta). Amzah.

Mauludi, S. (2018). Seri Cerdas Hukum; Cerdas Menghadapi Pencemaran Nama Baik, Ujaran Kebencian dan Hoaks. PT. Elek Media Komputindo.

MUSTIKA, P. P. (2019). Hoaks dan Ujaran Kebencian Berpotensi Muncul pada Pilkada 2020. Kompas.Com. https://kompas.id/baca/utama/2019/08/20/hoaks-dan-ujaran-kebencianmasih-berpotensi-muncul-pada-pilkada-2020/

Musyadi, H. (2005). Radikalisme Hancurkan Islam. Center of Moderate Muslim (CMM).

Rahman, Z. (2015). Surat Edaran Kapolri Tentang Ujaran Kebencian. Jurnal Rechts Online: 2015.

Riski, P. (2018). Beda Pendapan Di Sosmed Berakhir di Laras Senjata. Voa.Indonesia.

Shihab, M. Q. (2007). Wawasan Alquran; Tafsir Tematik Atas Pelbagai Persoalan Umat. Mizan.

Shihab, M. Q. (2014). Secercah Cahaya Illahi. Mizan.

Shihab, M. Q. (2017). Sopan Santun kepada Lawan atau Musuh. Tirto.Id. https://tirto.id/sopan-santun-kepada-lawan-atau-musuh-cqim 
Shihab, M. Q. (2017b). Tafsir Al-Misbah: Pesan, Kesan dan Keserasian Al-Quran (8th ed.). Lentera Hati.

Siberkreasi. (2019). Seri Literasi Digital, Demokrasi Damai Era Digital. Gerakan Nasional Literasi Digital. 